\title{
ПРАВОВЫЕ РЕЖИМЫ, ОСНОВАННЫЕ НА ОГРАНИЧЕНИЯХ: К ОПРЕДЕЛЕНИЮ ПОНЯТИЯ
}

\begin{abstract}
Аннотация: В статье реализована попытка комплексного общетеоретического рассмотрения правового режима, основанного на ограничениях. Рассмативается понятие правовых ограничений, их соотношение с правовыми запретами и особенности реализации в условиях соотвествующих правовых режимов. Анализируются признаки правового режима. основанного на ограничениях, предлагается его авторское определение. В целях недопущения произвольного ограничения прав и свобод граждан, злоупотребления со стороны органов государственной власти в данной сфере предложены критерии ограничения данных прав в условиях ограничивающих правовых режимов. Общенаучные методы в основном нашли применение в теоретическом обосновании проблемы, при рассмотрении вопросов понимания феномена правового режима, определения его значимости в процессе правового регулирования. Комплексный теоретико-прикладной междисииплинарный подход к исследованию правовых режимов обусловил необходимость использования в работе системного метода, в рамках которого осуществлено интегрирование теоретических абстракиий и положений, закрепленных в действующем законодательстве. Проанализирован специальный правовой режим, представляющий модификацию общего и устанавливающий особые ограничения для субъектов в рамках режимного регулирования, в результате чего определено его понятие, признаки и содержание; охарактеризованы правовые ограничения, лежащие в основе этого режима, а также выработаны критерии ограничения прав и свобод граждан в условиях чрезвычайных правовых режимов.

Ключевые слова: Правовой режим, специальный правовой режим, общий правовой режим, сущность правового режима, правовое ограничение, правовой запрет, принципы, гарантии, цели, критерии ограничения прав.

Abstract: This article presents a complex general theoretical examination of a legal regime based on restrictions. The author examines the notions of legal restrictions, their correlation with legal prohibitions, and specificity of its realization under the conditions of existing legal regimes. The legal regime based on restrictions is being analyzed, and the author proposes an original definition. In order to prevent arbitrary limitation of rights and liberties of citizens, and abuse of these rights by the branches of government authorities, the author offers criteria for limitation of such rights in the conditions of restrictive legal regimes. The general scientific methods were applied for the theoretical substantiation of the problem during the review of the questions of cognition of the phenomenon of legal regime, and determination of its significance in the process of legal regulation.
\end{abstract}

Keywords: Legal regime, Special legal regime, General legal regime, Essence of legal regime, Legal restriction, Legal prohibition, Principles, Guarantees, Goals, Criteria for limitation of rights.

Публикация подготовлена в рамках выполнения государственного задания Министерства образования и науки Российской Федераиии по теме: «Юридическая деятельность и ее прочессуальное оформление» (заявка 2014/ 78)

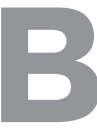
настоящее время, когда понятие «правовой режим» широко используется в нормативноправовых актах различного уровня, научной литературе, является важной категорией в общей теории права и отраслевых науках, нельзя не обратить внимание на тот факт, что оно остается одним из наи- более сложных и недостаточно изученных в юридической науке.

Проблема усугубляется еще и тем, что даже в рамках узкоотраслевых исследований понятие правового режима часто используется как «обиходное», уже известное и не нуждающееся в уточнении. В ис- 
DOI: $10.7256 / 1811-9018.2015 .8 .10725$

При цитировании этой статьи сноска на dоі обязательна

\section{Право и политика 8 (188) • 2015}

следованиях подобного рода правовой режим нередко упоминается только в названии работы. Как результат, растет количество научных трудов, в которых данное понятие употребляется применительно к объектам правового регулирования (особенно в отраслях права), видам деятельности, субъектам права и т.д. подчас относительно свободно и часто неоправданно, без учета предназначения и истинной сущности рассматриваемой категории в системе правового регулирования.

Как следствие, в целях преодоления узкоотраслевого понимания правовых режимов (по сути, сведения их к определению объектов права) и неоправданного использования их в контексте нормативно-правовых актов и научных исследований необходима постановка проблемы изучения правовых режимов как фундаментального общетеоретического направления.

Решению данной проблемы в определенной степени способствует и представленное исследование, в котором реализована попытка определить сущность и содержание такого явления, как «правовой режим, основанный на ограничениях».

Сущность (основное предназначение) любого правового режима состоит в установлении на определенном участке правовой действительности особого порядка (климата, напряженности) правового регулирования, заключающегося в создании для субъектов права преимуществ (стимулов, льгот и т.д.) или ограничений (обязываний, запретов и т.д.) в целях реализации прав и законных интересов последних.

В юридической науке распространены два основных подхода к классификации правовых режимов в рассматриваемой плоскости.

Согласно первому подходу, в свое время предложенному С.С. Алексеевым, по соотношению типов (способов) правового регулирования правовые режимы принято делить на общедозволительные, разрешительные и основанные на позитивном обязывании ${ }^{1}$.

Согласно второму подходу, по соотношению стимулов и ограничений отдельные авторы выделяют стимулирующие и ограничивающие правовые режимы с соответствующими подвидами: дозволительные, рекомендательные, обязывающие, запрещающие и т.д. ${ }^{2}$.

Следует отметить, что некоторые различия в названной терминологии при достаточной схожести подходов в определении сущностных свойств правовых

\footnotetext{
${ }^{1}$ См.: Алексеев С.С. Общие дозволения и общие запреты в советском праве. М., 1989. С. 190-191.

${ }^{2}$ См. напр.: Малько A.B., Родионов O.C. Правовые режимы в российском законодательстве // Журнал российского права. 2001. № 9. С. 19-22.
}

режимов, объясняются различным углом зрения на феномен правового режима.

Так, С.С. Алексеев под правовым режимом понимает «порядок регулирования, выраженный в комплексе правовых средств, характеризующих особое сочетание взаимодействующих между собой дозволений, запретов, а также позитивных обязываний и создающих особую направленность регулирования»³.

Основной акцент в определении правового режима ученый делает на создание особой направленности регулирования путем сочетания определенных средств и способов такового, поэтому в наименовании видов правового режима указывается на типы правового регулирования, преимущественно лежащие в их основе - общедозволительные (в основе которых дозволения), разрешительные (в основе - запреты), и основанные на позитивном обязывании (обязанности).

В то же время, в своих рассуждениях о правовых режимах С.С. Алексеев признает, что «каждый правовой режим есть все же именно режим; следует принимать во внимание основные смысловые оттенки этого слова, в том числе и то, что правовой режим выражает степень жесткости юридического регулирования, наличие известных ограничений или льгот...» ${ }^{4}$, «... первичные правовые режимы выражают соотношения способов регулирования на определенном участке социальной жизни; вторичные - модификации правовых режимов, вносящие либо особые льготы и преимущества, состоящие в дополнительных правах, либо особые ограничения, которые заключаются в дополнительных запретах или позитивных обязываниях»

В свою очередь, другие авторы в определении правового режима как «особого порядка регулирования, выражающегося в определенном сочетании юридических средств и создающего желаемое социальное состояние и конкретную степень благоприятности либо неблагоприятности для удовлетворения интересов субъектов права ${ }^{6}$ ориентируются на информационнопсихологический подход, где стимулы, основанные на дозволительном типе правового регулирования, побуждают субъекта права к позитивному поведению и создают для него режим благоприятствования, а

\footnotetext{
${ }^{3}$ Алексеев С.С. Общие дозволения и общие запреты в советском праве. С. 185.

${ }^{4}$ Алексеев С.С. Теория права. 2-е изд. М., 1995. С. 244.

${ }^{5}$ Алексеев С.С. Общие дозволения и общие запреты в советском праве. С. 190.

${ }^{6}$ См., напр.: Матузов Н.И., Малько А.В. Правовые режимы: вопросы теории и практики // Известия вузов. Правоведение. 1996. № 4. С. 17-18.
} 
ограничения, основанные на разрешительном типе правового регулирования и позитивных обязываниях, ограничивают противоправное поведение субъектов (режим неблагоприятствования) и создают условия для реализации прав и законных интересов других лиц (контрагентов).

В результате, и в первом, и во втором случае отмечается четкая обусловленность правовых режимов типом (способом) правового регулирования, и в то же время, хотя и по-разному акцент делается на особую направленность правового регулирования, основанную на специфическом сочетании правовых средств, в первом случае, и на степень благоприятности (неблагоприятности) для удовлетворения интересов субъектов права (информационно-психологический аспект) - во втором случае.

В то же время, и в том, и другом случае учеными признается тот факт, что правовые режимы создают для субъектов права либо особые преимущества, либо особые ограничения.

В этой связи со своей стороны считаем возможным предложить следующее наименование двух больших групп правовых режимов:

- правовые режимы, основанные на преимуществах, в основе которых лежит общедозволительный тип правового регулирования (льготы, привилегии, иммунитеты, поощрения и т.д.);

- правовые режимы, основанные на ограничениях, в основе которых - преимущественно разрешительный тип правового регулирования и позитивные обязывания (запреты, обязанности, приостановления, наказания и т.д.) ${ }^{7}$

Перейдем к изучению правовых режимов, основанных на ограничениях.

Наиболее сложным в рамках названной проблемы представляется вопрос о соотношении правового ограничения и правового запрета, который мы предлагаем рассматривать в контексте определения понятия правового ограничения, высказанного в науке.

Например, Ф.Н. Фаткуллин характеризует ограничение как понятие, близкое к запрету, однако рассчитанное не на полное вытеснение того или иного общественного отношения, а на удержание его в жестко ограничиваемых рамках ${ }^{8}$. Тем самым ограничение автором определяется как запрет, но не реализованный в полном объеме.

\footnotetext{
${ }^{7}$ См.: Беляева Г.С. Правовой режим в общетеоретическом измерении. М., 2013.

${ }^{8}$ См.: Фаткуллин Ф.Н. Проблемы теории государства и права.
} Казань, 1987. С. 157.
В свою очередь, ряд авторов считает ограничение самостоятельным способом правового регулирования9.

Некоторые авторы рассматривают правовое ограничение как родовое понятие по отношению к правовому запрету по формуле: всякий запрет - есть ограничение, но не всякое ограничение в сфере права - запрет ${ }^{10}$.

А.В. Малько видит в правовых ограничениях сдерживание противозаконного деяния, создающее условия для удовлетворения интересов контрсубъекта и общественных интересов в охране и защите; это установленные в праве границы, в пределах которых субъекты должны действовать; исключение определенных возможностей в деятельности лиц ${ }^{11}$.

Надо заметить, что позиция этого ученого получила поддержку и на отраслевом уровне ${ }^{12}$.

В юридической литературе существует мнение о том, что установленные законодательством ограничения прав государственных гражданских служащих являются их своеобразными гражданскими обязанностями ${ }^{13}$.

Данный вывод отчасти подтверждается отдельными положениями законодательства. Так, ст. 17 Федерального закона от 27 июля 2004 г. № 79-Ф3 «О государственной гражданской службе Российской Федерации» содержит перечень запретов, связанных с гражданской службой. Часть 2 данной статьи гласит: «В случае если владение гражданским служащим приносящими доход ценными бумагами, акциями ... может привести к конфликту интересов, он обязан передать принадлежащие ему указанные ценные бумаги ... в доверительное управление...». То есть здесь ограничение (запрет) реализуется через обязанность.

Однако в данном случае речь идет, скорее всего, о некотором частном случае, приеме законодательной техники, исходя из которых нельзя делать обобщающие

\footnotetext{
9 См.: Братко А.Г. Запреты в советском праве. Саратов, 1979; Рыбушикин Н.Н. Запрещающие нормы в советском праве. Казань, 1990; Семенюта Н.Н. Запреты и ограничения в правовом регулировании трудовых отношений в Российской Федерации: Автореф. дис... канд. юрид. наук. Екатеринбург, 2000.

${ }^{10}$ См.: Приходько И.М. Ограничения в российском праве (проблемы теории и практики). Автореф. дис. ...канд. юрид. наук. Саратов, 2002. С. 8-9.

${ }^{11}$ См.: Малько А.В. Стимулы и ограничения в праве. М.. 2003. С. 91.

${ }^{12}$ См.: Ашихмина А.В. Конституционно-правовой механизм ограничения прав и свобод человека и гражданина в Российской Федерации. Автореф. дис. ...канд. юрид. наук. М., 2009. С. 12-13.

${ }^{13}$ См., напр.: Конин Н.М. Административное право. Общая часть. Саратов, 2001; Кузнецов К.В. Роль правовых ограничений в системе российского публичного права // Известия Иркутской государственной экономической академии. 2012. № 5 (85). С. 119.
} 
DOI: $10.7256 / 1811-9018.2015 .8 .10725$

При цитировании этой статьи сноска на доі обязательна

\section{Право и политика 8 (188) 2015}

выводы, поскольку главное в правовых ограничениях - это то, что они очерчивают границы разрешенного поведения субъектов.

Для установления признаков правового ограничения можно привести и следующее его определение.

С учетом приведенных точек зрения попытаемся сформулировать свою позицию относительно сущности правового ограничения и его соотношения с другими юридическими категориями (в частности, запретами и обязываниями (предписаниями)). Прежде всего, относительно выделения ограничения как самостоятельного способа правового регулирования сошлемся на С.С. Алексеева, который отмечает, что ограничение или расширение прав - это вопрос не о способе, а об объеме регулирования, что достигается через сужение дозволений, новых запретов, дополнительных позитивных обязанностей ${ }^{14}$. Далее, полагаем, что нет необходимости рассматривать ограничение вместе с дозволениями, запретами и предписаниями в качестве способов правового регулирования, поскольку в данном случае ограничение выступает как некий специфический процесс (или результат $\left.^{15}\right)$, который может достигаться посредством этих способов; правовое ограничение следует понимать как обобщающее понятие, которое реализуется через все вышеперечисленные способы правового регулирования, однако в большей степени через запреты и позитивные обязывания.

По вопросу соотношения ограничения и запрета (или обязывания) как общего и частного считаем, что ограничение может становиться правовым запретом или обязанностью лишь на уровне диспозиции конкретной правовой нормы, и только тогда указанная конструкция может считаться полностью справедливой.

Данная позиция по отождествлению ограничений и запретов в ряде случаев разделяется и законодателем. Так, в соответствии со ст. 27 Лесного кодекса РФ допускается установление следующих ограничений использования лесов: а) запрет на осуществление одного или нескольких видов использования лесов, предусмотренных частью 1 статьи 25 Кодекса; б) запрет на проведение рубок.

Что же касается соотношения ограничения как некоего процесса, результата и общего запрета, позитивного обязывания как способов правового регулирования, то здесь ограничение реализуется посредством

\footnotetext{
${ }^{14}$ См.: Алексеев С.С. Общие дозволения и общие запреты в советском праве. С. 65.

15 Там же. С. 66.
}

последних и может выражаться во временном изменении объема субъективного права (его умалении, полном лишении, приостановлении), установлении конкретных запретов, обязанностей, лимитов, цензов, мер наказания, принуждения и т.д.

Проведенный анализ точек зрения относительно понятия и сущности правовых ограничений и свой подход к рассматриваемой проблеме позволяет выделить их основные признаки:

- носят нормативно-правовой характер, то есть подлежат закреплению в действующем законодательстве;

- создают неблагоприятные (а иногда и сверхнеблагоприятные) условия для удовлетворения собственных интересов субъектов, направлены на их сдерживание и одновременно на удовлетворение интересов контрагентов, либо охраняемых государством общественных интересов;

- выражаются в уменьшении объема прав (свобод, иных возможностей) субъекта;

- реализуются, как правило, посредством общих правовых запретов и позитивных обязываний;

- находят выражение в таких правовых средствах, как приостановление, установление лимитов, цензов, наказания, мер принуждения (пресечения) и т.д.;

- направлены на сдерживание противоправного или нежелательного для государства поведения личности, защиту общественных интересов.

Продолжая исследование, вернемся к понятию правового режима, основанного на ограничениях.

Отметим, что в юридической литературе данный правовой режим, в основе которого лежит разрешительный тип правового регулирования, рассматривается следующим образом.

С.С. Алексеев определяет его как вторичный (модификацию первичного правового режима), вносящий особые ограничения, которые заключаются в дополнительных запретах или позитивных обязываниях ${ }^{16}$.

В этом определении, полагаем, содержится ценная информация о том, что рассматриваемый правовой режим является подвидом (модификацией) правового режима в целом, а также указание на способы правового регулирования, преимущественно используемые в рамках данного правового режима.

В свою очередь, А.В. Малько, характеризуя ограничивающий правовой режим, пишет, что в отличие от стимулирующего правового режима, создающего благоприятные условия для удовлетворения конкретной

\footnotetext{
${ }^{16}$ См.: Алексеев С.С. Общие дозволения и общие запреты в советском праве. С. 190.
} 
группы интересов, ограничивающий правовой режим нацелен на их комплексное сдерживание. Кроме того, среди правовых режимов ограничения ученый выделяет обязывающий, запрещающий, наказывающий и т.п. ${ }^{17}$

В данном определении содержатся другие существенные характеристики рассматриваемых правовых режимов, а именно указание на такой признак, как комплексное сдерживание интересов, а также на их классификацию.

И.Р. Забугин определяет специальный ограничивающий правовой режим как установленный нормами права и обеспечиваемый государством порядок правового регулирования деятельности, объектов (территорий), представленный негативными ограничивающими средствами и создающий конкретную степень неблагоприятствования, целью которого является правовое сдерживание противозаконного деяния и создающего условия для удовлетворения интересов контрсубъекта и общественных интересов в охране и защите ${ }^{18}$.

Свое мнение по поводу определения правового режима данным автором мы уже высказывали ранее (в частности, относительно определения объектов режимного регулирования). Другие аспекты этого определения отметим далее при характеристике признаков правового режима, основанного на ограничениях.

Bo-nервых, правовой режим, основанный на ограничениях, является видом (модификацией) правового режима в целом, который отличает используемый им специфический набор правовых средств, сдерживающих (устанавливающих препятствия) для реализации прав, свобод и законных интересов субъектов права. Это лимиты, цензы, меры наказания, принуждения (пресечения) и т.д.

Например, в ст. 1 Федерального конституционного закона от 30.01.2002 № 1-ФКЗ «О военном положении» закрепляется, что в период действия военного положения могут в той мере, в какой это необходимо для обеспечения обороны страны и безопасности государства, ограничиваться права и свободы граждан Российской Федерации, иностранных граждан, лиц без гражданства, деятельность организаций независимо от организационно-правовых форм и форм собственности, права их должностных лиц. На граждан, организации и их должностных лиц могут возлагаться дополнительные обязанности.

\footnotetext{
${ }^{17}$ См.: Малько А.В. Стимулы и ограничения в праве. С. 209.

${ }^{18}$ См.: Забугин И.Р. Специальный правовой режим ограничения // Вектор науки Тольяттинского государственного университета. 2011. № 1(4). С. 71.
}

Данный ограничивающий режим является модификацией общего правового режима, действующего в мирное время и закрепленного Конституцией РФ и текущим (ординарным) законодательством Российской Федерации и ее субъектов.

Bo-вторыx, он представляет собой особый порядок правового регулирования, основанный на таких способах правового регулирования, как общие запреты, позитивные обязывания и соответствующих средствах правового регулирования (конкретных запретах, приостановлениях, обязанностях, лимитах, цензах, мерах наказания, принуждения и т.д.).

При характеристике данного признака мы сознательно обходим вопрос о принадлежности данного правового режима к определенному типу правового регулирования, поскольку его нельзя назвать разрешительным, ведь в его основе лежат не только заперты, но и позитивные обязывания. Его сущностную характеристику можно, скорее, определить словосочетанием предписывающе-запрещающий или обязывающе-запрещающий. Тем более, что юридической наукой все чаще предпринимаются попытки выявить новые типы правового регулирования в рамках ряда отраслей права ${ }^{19}$.

$B$-третьих, правовой режим, основанный на ограничениях, базируется на системе основополагающих принципов, характерных как для всех видов правовых режимов, так и специализированных принципов, свойственных исключительно рассматриваемым правовым режимам.

К таким специализированным принципам можно отнести принципы гуманизма, ориентации на интересы человека, соразмерности правовых ограничений, обеспечения правосудием и другие.

$B$-четвертых, правовыми гарантиями режима, основанного на ограничениях, выступают нормативно закрепленные правовые условия, средства (в т.ч. и механизмы), призванные обеспечить исполнение обязанностей, ограничений, запретов - при ограничивающем правовом режиме.

Так, в Земельном кодексе РФ гарантией охраны правового режима земель в Российской Федерации выступает административная и уголовная ответственность за земельные правонарушения (ст. 74 ЗК РФ).

$B$-nятых $x$, нормативно-правовое закрепление правового режима, основанного на ограничениях, имеет определенные особенности: для правового режима раз-

\footnotetext{
${ }^{19}$ См., напр.: Зырянов С.M. Разрешительные режимы в российском административном праве // Журнал российского права. 2012. № 11. C. $39-48$.
} 
DOI: $10.7256 / 1811-9018.2015 .8 .10725$

При цитировании этой статьи сноска на доі обязательна

\section{Право и политика 8 (188) 2015}

решительного профиля свойственна такая юридическая конструкция, при которой субъекты обладают только теми правами, которые прямо предусмотрены в нормативных правовых актах, а общему запрету соответствуют конкретно определенные законодателем дозволения.

Примером может служить правовой режим лесов, расположенных на особо охраняемых природных территориях (ст. 103 Лесного кодекса РФ). Так, в ч. 2 ст. 103 Лесного кодекса РФ содержится запрет: «В лесах, расположенных на территориях государственных природных заповедников, запрещается проведение рубок лесных насаждений на лесных участках, на которых исключается любое вмешательство человека в природные процессы.». А в дальнейшем тексте данной статьи - дозволение, в частности, норма о том, что «На иных участках, если это не противоречит правовому режиму особой охраны территорий государственных природных заповедников, допускается проведение выборочных рубок лесных насаждений в целях обеспечения функционирования государственных природных заповедников и жизнедеятельности проживающих в их пределах граждан».

Важно заметить, что правовой режим, основанный на ограничениях, детально разработан, как правило, содержит в себе исчерпывающий перечень субъектов, объектов, средств правового регулирования и т.д., не предусматривает для актов нижестоящих органов и должностных лиц вариативности поведения.

Например, ст. 11 Федерального конституционного закона от 17 декабря 1997 г. «О Правительстве Российской Федерации» ${ }^{20}$ содержит являющийся исчерпывающим перечень ограничений, связанные с пребыванием в составе Правительства Российской Федерации.

$B$-шестых, цель правового режима, основанного на ограничениях, равно как и в случае с режимами, основанными на преимуществах, не является специфическим признаком данного вида правового режима.

В этом плане нельзя согласиться с мнением И.Р. Забугина, который считает, что целью правового режима ограничения является «сдерживание противозаконного поведения $»^{21}$, поскольку это самое «сдерживание» проявляется не как цель правового режима ограничения вообще, а лишь как цель правового ограничения внутри правового режима.

\footnotetext{
${ }^{20}$ С3 РФ. 1997. № 51. Ст. 5712.

${ }^{21}$ См.: Забугин И.Р. Специальный правовой режим ограничения // Вектор науки Тольяттинского государственного университета. 2011. № 1(4). С. 71.
}

В целом же все правовые режимы направлены на удовлетворение интересов субъектов права, обеспечение нормального функционирования общественных отношений. Вопрос «сдерживания противозаконного поведения» тем самым лежит в плоскости направлений действия правовых режимов, а не целей правового регулирования и относится скорее к информационнопсихологическому аспекту функционирования правовых режимов.

Кроме того, следует обратить внимание и на узость формулировки так называемой «цели» ограничивающего правового режима, поскольку в его рамках «сдерживаться» может также и правомерное поведение.

Речь, в частности идет, о функционировании чрезвычайных правовых режимов.

Так, согласно названной ст. 1 Федерального конституционного закона от 30.01.2002 № 1-ФКЗ «О военном положении» в период действия военного положения могут в той мере, в какой это необходимо для обеспечения обороны страны и безопасности государства, ограничиваться права и свободы граждан Российской Федерации, иностранных граждан, лиц без гражданства, деятельность организаций независимо от организационно-правовых форм и форм собственности, права их должностных лиц (подчеркнуто нами - Г.Б.).

$B$-ceдbsыx, из изложенного выше вытекает такой признак правового режима, основанного на ограничениях: как создание неблагоприятных условий для субъектов права для реализации своих интересов.

Правовой режим ограничения (в противовес режиму стимулирующего характера) создает для определенных субъектов права режим неблагоприятности, поскольку, по верному выражению А.В. Малько, направлен на сдерживание их интересов и одновременно на удовлетворение интересов противостоящей стороны в правоотношении и общественных интересов в охране и защите ${ }^{22}$.

Тот же пример: в соответствии с ч. 4 ст. 1 Федерального конституционного закона от 30.01.2002 № 1-ФКЗ «О военном положении» в период действия военного положения в соответствии с названным Федеральным конституционным законом могут в той мере, в какой это необходимо для обеспечения обороны страны и безопасности государства, ограничиваться права и свободы граждан Российской Федерации, иностранных граждан, лиц без гражданства, деятельность организаций независимо от организационно-правовых форм и форм собственности, права их должностных

\footnotetext{
${ }^{22}$ См.: Малько А.В. Стимулы и ограничения в праве. С. 91.
} 
лиц. На граждан, организации и их должностных лиц могут возлагаться дополнительные обязанности.

Правовой режим, основанный на ограничениях, в большей мере устанавливается и функционирует в отношении государства, государственных органов и государственных служащих.

Суммируя вышесказанное, можно констатировать, что обязанности и запреты как первичные способы правового ограничения находят свое отражение в основных формах ограничения государственной власти - разделении властей, федерализме, верховенстве закона, взаимной ответственности личности и государства, которые являются более объемными (комплексными) правовыми ограничивающими средствами (инструментами).

Однако надо отметить, что правовой режим, основанный на ограничениях, может устанавливаться также в отношении, как отдельных граждан, так и организаций.

Так, в ч. 3 ст. 55 Конституции РФ закреплено, что права и свободы человека и гражданина могут быть ограничены федеральным законом только в той мере, в какой это необходимо в целях защиты основ конституционного строя, нравственности, здоровья, прав и законных интересов других лиц, обеспечения обороны страны и безопасности государства.

Правовые режимы, основанные на ограничениях прав и свобод граждан, помимо конституционно-правовой и административно-правовой сферы, распространены также в гражданском, финансовом, экологическом и других отраслях законодательства.

Например, в гражданском праве в соответствии со ст. 43 Федерального закона от 26.12.1995 № 208-Ф3 «Об акционерных обществах» ${ }^{23}$ установлен правовой режим, основанный на ограничениях по выплате дивидендов. Так, общество не вправе принимать решение (объявлять) о выплате дивидендов по акциям: до полной оплаты всего уставного капитала общества; до выкупа всех акций; если на день принятия такого решения общество отвечает признакам несостоятельности (банкротства) в соответствии с законодательством Российской Федерации о несостоятельности (банкротстве) или если указанные признаки появятся у общества в результате выплаты дивидендов и т.д.

В рамках экологического законодательства Лесной кодекс РФ устанавливает правовой режим, основанный на ограничениях использования лесов. Так, ст. 27 Лесного кодекса РФ в рамках соответствующего право-

\footnotetext{
${ }^{23}$ СЗ. РФ. 1996 № 1. Ст. 1.
}

вого режима установлены запрет на осуществление одного или нескольких видов использования лесов, предусмотренных частью 1 статьи 25 Кодекса; запрет на проведение рубок; иные установленные Кодексом, другими федеральными законами ограничения использования лесов.

Ограничение прав и свобод граждан устанавливается в законодательных актах двумя основными способами: либо путем закрепления дополнительных условий, запретов и обязанностей, стесняющих реализацию субъективных прав и свобод, либо путем увеличения полномочий органов государственной власти и их должностных лиц, либо обоими этими способами одновременно. Результат в данном случае один - сокращение вариантов возможного поведения, составляющих содержание субъективных прав и свобод граждан.

Отметим, что предусмотренные законодательством формы ограничения прав и свобод граждан могут быть различными:

а) запрет на определенный вариант реализации права или свободы, то есть установление границ поведения (относительный запрет). Например, ограничение движения транспортных средств и осуществление их досмотра (п. 11 ч. 2 ст. 7 Федерального конституционного закона «О военном положении»);

б) запрет на реализацию права (свободы) в целом (или абсолютный запрет). К примеру, запрещение забастовок и иных способов приостановления или прекращения деятельности организаций (п. 10 ч. 2 ст. 7 Федерального конституционного закона «О военном положении»);

в) вмешательство (вторжение) в субъективное право (свободу) гражданина уполномоченных государственных органов. Например, предоставление федеральным органам исполнительной власти, органам исполнительной власти субъектов Российской Федерации и органам военного управления права при необходимости осуществлять проверку документов, удостоверяющих личность граждан, личный досмотр, досмотр их вещей, жилища и транспортных средств, а по основаниям, установленным федеральным законом, - задержание граждан и транспортных средств (п. 12 ч. 2 ст. 7 Федерального конституционного закона «О военном положении»);

г) обязанность. К примеру, привлечение граждан в порядке, установленном Правительством Российской Федерации, к выполнению работ для нужд обороны, ликвидации последствий применения противником оружия, восстановлению поврежденных (разрушен- 
DOI: $10.7256 / 1811-9018.2015 .8 .10725$

При цитировании этой статьи сноска на dоі обязательна

\section{Право и политика 8 (188) 2015}

ных) объектов экономики, систем жизнеобеспечения и военных объектов, а также к участию в борьбе с пожарами, эпидемиями и эпизоотиями (п. 6 ч. 2 ст. 7 Федерального конституционного закона «О военном положении»);

д) ответственность. Например, в соответствии со ст. 3.9 КоАП РФ административный арест, в обычных условиях установленный на срок до пятнадцати суток, за нарушение требований режима чрезвычайного положения или правового режима контртеррористической операции может быть назначен на срок до тридцати суток.

По нашему убеждению, в целях недопущения произвольного ограничения прав и свобод граждан и недопущения злоупотребления со стороны органов государственной власти в данной сфере необходимы четкие критерии ограничения данных прав:

- правовой основой ограничения прав человека должен быть только закон - Конституция РФ (основной закон), федеральный конституционный или федеральный законы;

- цель ограничения прав человека - защита основ конституционного строя, нравственности, здоровья, прав и законных интересов других лиц, обеспечения обороны страны и безопасности государства (ч. 3 ст. 55 Конституции РФ);

- условия установления подобных ограничений (необходимы в совокупности) - реальная или потенциальная возможность причинения вреда государственным и общественным интересам; невозможность защиты указанных интересов иными способами; соразмерность вводимых ограничений; причиняемый вред меньше, чем предотвращаемый ${ }^{24}$;

- ограничения должны носить общий (неперсонифицированный) характер, не иметь обратной силы и не изменять сущность самого ограничиваемого конституционного права (свободы);

- ограничения должны соответствовать общепризнанным принципам и нормам международного права;

- ограничения не должны касаться фундаментальных прав и свобод человека и носить дискриминационный характер;

- правовая норма, ограничивающая права и свободы граждан, должна быть четко сформулирована и не допускать произвольного (распространительного или ограничительного) толкования.

Суммируя вышесказанное, правовой режим, основанный на ограничениях, можно определить как особый порядок правового регулирования общественных отнотений, основанный на определенном сочетании правовых средств - общих запретов и позитивных обязываний (приостановлений, обязанностей, цензов, лимитов, мер государственного принуждения и наказания и т.д.), гарантий и принципов, направленный путем создания неблагоприятных условий для удовлетворения собственных интересов субъектов права на достижение оптимального сочиального состояния.

\section{Библиография:}

1. Алексеев С.С. Общие дозволения и общие запреты в советском праве. М., 1989.

2. Ашихмина А.В. Конституционно-правовой механизм ограничения прав и свобод человека и гражданина в Российской Федерации. Автореф. дис. ...канд. юрид. наук. М., 2009.

3. Беляева Г.С. Правовой режим в общетеоретическом измерении. М., 2013.

4. Братко А.Г. Запреты в советском праве. Саратов, 1979; Рыбушкин Н.Н. Запрещающие нормы в советском праве. Казань, 1990

5. Брыкин Д.М. Принципы ограничения прав и свобод граждан в условиях особых правовых режимов // Бизнес в законе. 2010. № 4.

6. Забугин И.Р. Специальный правовой режим ограничения // Вектор науки Тольяттинского государственного университета. 2011. № 1(4).

7. Зырянов С.М. Разрешительные режимы в российском административном праве // Журнал российского права. 2012 . № 11.

8. Кузнецов К.В. Роль правовых ограничений в системе российского публичного права // Известия Иркутской государственной экономической академии. 2012. № 5 (85).

9. Малько А.В., Родионов О.С. Правовые режимы в российском законодательстве // Журнал российского права. 2001 . № 9.

10. Малько А.В. Стимулы и ограничения в праве. М., 2003.

11. Матузов Н.И., Малько А.В. Правовые режимы: вопросы теории и практики // Известия вузов. Правоведение. 1996. № 4.

12. Приходько И.М. Ограничения в российском праве (проблемы теории и практики). Автореф. дис. ...канд. юрид. наук. Саратов, 2002.

13. Рыбушкин Н.Н. Запрещающие нормы в советском праве. Казань, 1990.

14. Семенюта Н.Н. Запреты и ограничения в правовом регулировании трудовых отношений в Российской Федерации: Автореф. дис... канд. юрид. наук. Екатеринбург, 2000.

\footnotetext{
${ }^{24}$ См.: Брыкин Д.М. Принципы ограничения прав и свобод граждан в условиях особых правовых режимов // Бизнес в законе. 2010. № 4. C. 10-11.
} 
15. Трегубова Е.В. Административный механизм реализации правового запрета: понятие, признаки, система. Часть 2 // Административное и муниципальное право. - 2010. - 7. - С. 68-80.

16. Трегубова Е.В. Административной механизм реализации правового запрета: понятие, признаки, система (часть 1) // Административное и муниципальное право. - 2010. - 5. - С. 76-91.

17. Фаткуллин Ф.Н. Проблемы теории государства и права. Казань, 1987

18. Купреев С.С. Правовой режим пребывания иностранцев в Российской Федерации в условиях проведения Олимпийских зимних игр 2014 г. в городе Сочи // NB: Административное право и практика администрирования. - 2013. - 12. - C. 21 - 34. URL: http://www.e-notabene.ru/al/article_10699.html

19. Афанасьев А.А. Муниципально-правовой режим сельской жизни: понятие и сущность местного самоуправления сельских поселений // NB: Экономика, тренды и управление. - 2013. - 3. - C. 17 - 50. URL: http://www.e-notabene.ru/etc/ article_7423.html

20. Гуляихин В.Н. Структурно-функциональные особенности различных состояний правосознания человека // NB: Вопросы права и политики. -2012.-2. -C. 90 - 116. DOI: 10.7256/2305-9699.2012.2.153. URL: http://www.e-notabene.ru/lr/article_153.html

21. Жидких А.А. Правовое регулирование и практика участия зарубежной прокуратуры в правотворчестве // NB: Вопросы права и политики. - 2013. - 10. - C. 104 - 130. URL: http:/www.e-notabene.ru/lr/article_807.html

22. С. Н. Бризецкий Конституционно-правовой режим гарантий прав инвалидов в Российской Федерации как пример обеспечения прав человека в формате верховенства права // Право и политика. - 2011. - 11. - С. 1924 - 1930.

23. Рыльская М.А. Особенности реализации специальных административных режимов // Административное и муниципальное право. - 2012. - 3. - С. $44-52$.

\section{References (transliterated):}

1. Alekseev S.S. Obshchie dozvoleniya i obshchie zaprety v sovetskom prave. M., 1989.

2. Ashikhmina A.V. Konstitutsionno-pravovoi mekhanizm ogranicheniya prav i svobod cheloveka i grazhdanina $\mathrm{v}$ Rossiiskoi Federatsii. Avtoref. dis. ...kand. yurid. nauk. M., 2009.

3. Belyaeva G.S. Pravovoi rezhim v obshcheteoreticheskom izmerenii. M., 2013.

4. Bratko A.G. Zaprety v sovetskom prave. Saratov, 1979; Rybushkin N.N. Zapreshchayushchie normy v sovetskom prave. Kazan', 1990

5. Brykin D.M. Printsipy ogranicheniya prav i svobod grazhdan v usloviyakh osobykh pravovykh rezhimov // Biznes v zakone. 2010. № 4.

6. Zabugin I.R. Spetsial'nyi pravovoi rezhim ogranicheniya // Vektor nauki Tol'yattinskogo gosudarstvennogo universiteta. 2011. № 1(4).

7. Zyryanov S.M. Razreshitel’nye rezhimy v rossiiskom administrativnom prave // Zhurnal rossiiskogo prava. 2012 . № 11.

8. Kuznetsov K.V. Rol' pravovykh ogranichenii v sisteme rossiiskogo publichnogo prava // Izvestiya Irkutskoi gosudarstvennoi ekonomicheskoi akademii. 2012. № 5 (85).

9. Mal'ko A.V., Rodionov O.S. Pravovye rezhimy v rossiiskom zakonodatel'stve // Zhurnal rossiiskogo prava. 2001 . № 9.

10. Mal'ko A.V. Stimuly i ogranicheniya v prave. M., 2003.

11. Matuzov N.I., Mal’ko A.V. Pravovye rezhimy: voprosy teorii i praktiki // Izvestiya vuzov. Pravovedenie. 1996. № 4.

12. Prikhod'ko I.M. Ogranicheniya v rossiiskom prave (problemy teorii i praktiki). Avtoref. dis. ...kand. yurid. nauk. Saratov, 2002.

13. Rybushkin N.N. Zapreshchayushchie normy v sovetskom prave. Kazan', 1990.

14. Semenyuta N.N. Zaprety i ogranicheniya v pravovom regulirovanii trudovykh otnoshenii v Rossiiskoi Federatsii: Avtoref. dis... kand. yurid. nauk. Ekaterinburg, 2000.

15. Tregubova E.V. Administrativnyi mekhanizm realizatsii pravovogo zapreta: ponyatie, priznaki, sistema. Chast' 2 // Administrativnoe i munitsipal'noe pravo. - 2010. - 7. - C. 68-80.

16. Tregubova E.V. Administrativnoi mekhanizm realizatsii pravovogo zapreta: ponyatie, priznaki, sistema (chast' 1)// Administrativnoe i munitsipal'noe pravo. - 2010. - 5. - C. 76-91.

17. Fatkullin F.N. Problemy teorii gosudarstva i prava. Kazan', 1987

18. Kupreev S.S. Pravovoi rezhim prebyvaniya inostrantsev v Rossiiskoi Federatsii v usloviyakh provedeniya Olimpiiskikh zimnikh igr 2014 g. v gorode Sochi // NB: Administrativnoe pravo i praktika administrirovaniya. - 2013. - 12. - C. 21 - 34. URL: http:// www.e-notabene.ru/al/article_10699.html

19. Afanas'ev A.A. Munitsipal'no-pravovoi rezhim sel'skoi zhizni: ponyatie i sushchnost' mestnogo samoupravleniya sel'skikh poselenii // NB: Ekonomika, trendy i upravlenie. - 2013. - 3. - C. 17 - 50. URL: http://www.e-notabene.ru/etc/article_7423.html

20. Gulyaikhin V.N. Strukturno-funktsional'nye osobennosti razlichnykh sostoyanii pravosoznaniya cheloveka// NB: Voprosy prava i politiki. - 2012. - 2. - C. 90 - 116. DOI: 10.7256/2305-9699.2012.2.153. URL: http://www.e-notabene.ru/lr/article_153.html

21. Zhidkikh A.A. Pravovoe regulirovanie i praktika uchastiya zarubezhnoi prokuratury v pravotvorchestve // NB: Voprosy prava i politiki. - 2013.-10. - C. $104-130$. URL: http://www.e-notabene.ru/lr/article_807.html

22. S. N. Brizetskii Konstitutsionno-pravovoi rezhim garantii prav invalidov v Rossiiskoi Federatsii kak primer obespecheniya prav cheloveka v formate verkhovenstva prava // Pravo i politika. - 2011. - 11. - C. $1924-1930$.

23. Ryl'skaya M.A. Osobennosti realizatsii spetsial'nykh administrativnykh rezhimov // Administrativnoe i munitsipal'noe pravo. -2012 . - 3. - C. $44-52$. 